\title{
Experimental study on waterproofing MDF with castor oil-based vegetal polyurethane
}

\author{
Eliana Paula Calegari ${ }^{1}$, Jussara Smidt Porto $^{1}$, Danieli Maehler Nejeliski ${ }^{1}$
} Lauren da Cunha Duarte ${ }^{1}$, Branca Freitas de Oliveira ${ }^{1}$

\author{
${ }^{1}$ Design and Graphic Expression, PGDesign, Federal University of Rio Grande do Sul, Porto Alegre, RS, Brazil, \\ elianapaulac@gmail.com, jussara.porto@ufrgs.br, danielinejeliski@yahoo.com.br, lauren.duarte@ufrgs.br, \\ branca@ufrgs.br
}

\begin{abstract}
This study aimed to analyze the waterproofing MDF with different coatings. For this, a comparative study was conducted with the following coatings on MDF: Vegetable polyurethane resin on castor oil-based, acrylic lacquer and marine varnish. To carry out the research, sewed up the samples in sequence, they received the coatings, and then we performed the test water absorption. As a result, the polyurethane resin to castor oil-based coating was presented the best results, that is, lower levels of water absorption lower thickness swelling and volume. Finally, it is believed that the study of waterproofing MDF plant originated from polyurethane castor oil is beneficial because it is a renewable source of material.
\end{abstract}

Keywords: MDF, waterproofing, vegetable polyurethane resin on castor oil-based.

\section{INTRODUCTION}

Wood is among the first materials used by humans. There are records of fires remains associated with clusters with more than 16,000 years [1]. Despite all the advances in materials engineering, especially as regards the development of synthetic materials, wood is still one of the main raw materials from renewable sources used in several areas. With the gradual increase in demand, it has become scarce in many parts of the world. Forests were decimated and planted comprise a cycle that takes decades for their growth, which eventually restricting the use of solid wood. This context prompted the search for new alternatives, and one of the most successful materials in this direction has been the MDF - Medium Density Fiberboard, a composite designed to replace wood, especially in furniture manufacturing.

According to ABIPA [2] MDF panel is produced from wood fibers bonded with synthetic resin through the application of high temperature and pressure. It has a compact appearance which makes it similar to the characteristics of massive wood, since the fibers basic components of the timber are all similar, in addition to its high density. Another favorable aspect is the use of waste arising from production processes that use wood as a raw material in the production of MDF. When produced from trees, the total utilization of raw material is much higher than in the manufacture of boards and planks, and irregular branches as parties may also be used. MDF, being a rectilinear material, spread-modulated in the manufacture of furniture.

The main characteristic of MDF boards is the great dimensional stability aspect in which the majority of wood species lacking. Being an extremely uniform material can be machined in different ways, both the edges, as the faces can be easily painted and coated turning grooved and perforated. Another important aspect of this material is that it does not have nodes, shafts and imperfections, which are typical of natural woods. Thus, the MDF is widely used in the furniture industry, used in tabletops, racks, shelves, drawer fronts, wardrobes, beds, with machining on edges or faces and others. In construction it is used as flooring, baseboards, door pillows, frames, doors and other machined. In addition, this material is being used in shop interiors, in showcases, such as walls, architectural moldings and other applications, its good machining and finishing their characteristics are used to advantage [2].

A recent survey by MOVERGS - Furniture Industries Association of Rio Grande do Sul state confirmed the importance of MDF in the furniture industry. The data show that, with respect to the materials used by industry, wooden furniture and derivatives account for $85 \%$ of total manufactured, both at country and in the state, and of these, the mobile series are the majority, $73.2 \%$ in Brazil and $69.4 \%$ in RS [3]. The $\mathrm{MDF}$, in addition to having a higher utilization in the production stage, also has the beneficiation process, 
manufacture of products derived. When working with solid wood material loss can reach $50 \%$ of the total, while with other materials derived from MDF and this number is very low, being between $10 \%$ and $20 \%$. Most of the loss of material is given by the lack of knowledge and planning, that is, due to the low quality feedstock, lack of knowledge of the material properties, poor planning, cutting plane and application of inadequate technologies [4].

However, if the MDF is subjected to extreme moisture conditions present in the fibers swell. This material has the characteristic of swell and not return to normal when in contact with moisture or water. The fibers immediately swell in a systematic process, affecting the material and damaging the panel and its characteristics [5]. This problem is aggravated in raw MDF panels that have no coating for protection. Thus, the moisture absorption is an aspect limiter for use of this material. To work around this aspect special coatings are used, and the search for improved solutions is constant. Concern for the waterproofing of all or part of organic materials is an old concern arose naturally as the man felt the need to extend the life of certain materials that came in contact with water.

Materials with such characteristics, called preservatives or waterproofing, have spread and evolved by applying the wood. The preservative treatments consist in protecting the permeable outer layers of the material against the action of Infestors bodies, to prevent the penetration and subsequent infestation of internal tissue layers [6]. Among the products used for chemical treatment of natural materials, the four most commonly used long-acting condoms and account for about $80 \%$ of the existing treated wood are creosote, pentachlorophenol, the chromated copper borate (CCB) and chromated copper arsenate (CCA) and the CCA is responsible for the largest volume of treated wood [7]. Chemical preservatives work very well in the task of waterproof material, however, are extremely toxic, many of them prohibited by specific laws in some countries, but they are still the most widely used.

Increasing environmental awareness and dissemination of mitigation and control of environmental impacts have served as a stimulus for further research in respect of preservatives products of wood and the like, with emphasis on new waterproofing materials that are nontoxic. As Moreschi [8] the development of alternative products for the treatment of wood it is of vital importance for the timber industry, but, contrary to what the practice has shown us, the intended benefits are not normally obtained in its fullness. According to the author [8] "for this to happen will require in addition to the protection given to wood, the harmfulness to humans is minimized or, if possible, eliminated." As the use of toxic materials is old, the natural preservatives such as linseed oil and natural waxes are too.

Many studies have been conducted focusing on non-toxic waterproofing products. With respect to new products developed, the polyurethane resin castor oil- based has proved to be an alternative when it comes to waterproofing materials. Castor oil is extracted from the castor seed (Ricinuscommunis) plant found in tropical and subtropical regions, abundant in Brazil. According to Dias [9], from this oil, it is possible to synthesize polyols and prepolymers with different characteristics which, when mixed lead to the cold polymerization, yielding a polyurethane resin castor base. By varying the percentage of components are different hardnesses of the final product achieved, catalysts may be employed in order to increase the polymerization rate. The resulting polyurethane has thermal stability up to $220^{\circ} \mathrm{C}$ trials indicate that occurs only a small mass loss. Because it is inert and nontoxic, it can be used in contact with drinking water and food, in addition to presenting properties such as surface waterproofing [10].

In this context, tests performed throughout this study aimed to verify the efficiency of the base polyurethane resin from castor oil as a waterproofing coating on MDF. In addition to the control samples without coating, samples were used coated with acrylic and marine varnish finishes consolidated in the market, in order to compare the results with the polyurethane resin from castor oil. The specimens were subjected to the water absorption test, it was observed the variation in the thickness and volume swell. Subsequently were analyzed in SEM - Scanning Electron Microscope, the better to observe changes in the surface of the MDF.

\section{MATERIALS AND METHODS}

Evaluation of proofing polyurethane resin based on castor oil on MDF was conducted by comparing samples from control of raw material, coated with polyurethane resin, acrylic lacquer and marine varnish. The methods used consist in the test water absorption, and scanning electron microscopy to check the morphology of the material before and after this test.

\subsection{Sample preparation}

For the production of test specimens used the raw MDF (without coating), because the presence of water 
absorption problems due the wood fibers exposed to moisture. Of the material flaps were acquired with thickness of $18 \mathrm{~mm}$, from the left of the sheet metal cutting joinery in the city of Porto Alegre. According to the manufacturer, the MDF is made from eucalyptus fibers.

Samples were cut in the size of $50 \mathrm{~mm}$ X $50 \mathrm{~mm}$ and then sanded to trim the edges. For waterproofing coating order, the following materials were used:

- Vegetal polyurethane resin on castor oil-based: this resin, amber, is bi-component, used for domestic and industrial floor coating, concrete, wood and carbon steel subjected to traffic of people and forklifts. and wood.

- Acrylic varnish: used to waterproof provides protection and brilliant finish in materials such as MDF

- Marine varnish: suitable for paintings of indoor and outdoor wood surface.

The vegetal polyurethane resin was donated by Imperveg company, and varnishes were commercially available. All these materials are national, and were followed the recommendations of use of the manufacturers. To perform the test, it was made three test pieces for each coating, as shown in Table 1:

Table 1: Description of test specimens.

\begin{tabular}{l|l}
\hline PROOF SAMPLE & \multicolumn{1}{c}{ COATING } \\
\hline $\mathrm{A} 1-\mathrm{A} 2-\mathrm{A} 3$ & Polyurethane resin on castor oil-based (3 coats) \\
\hline $\mathrm{B} 1-\mathrm{B} 2-\mathrm{B} 3$ & Acrylic varnish (3 coats) \\
\hline $\mathrm{C} 1-\mathrm{C} 2-\mathrm{C} 3$ & Marine varnish (3 coats) \\
\hline $\mathrm{D} 1-\mathrm{D} 2-\mathrm{D} 3$ & Uncoating \\
\hline
\end{tabular}

For proof samples coating with these materials, if used brush, as shown in Figure 1. Samples received 3 coats of material, moreover, were used in the proof samples without coating, for comparison purposes absorption water and thickness swelling and volume.

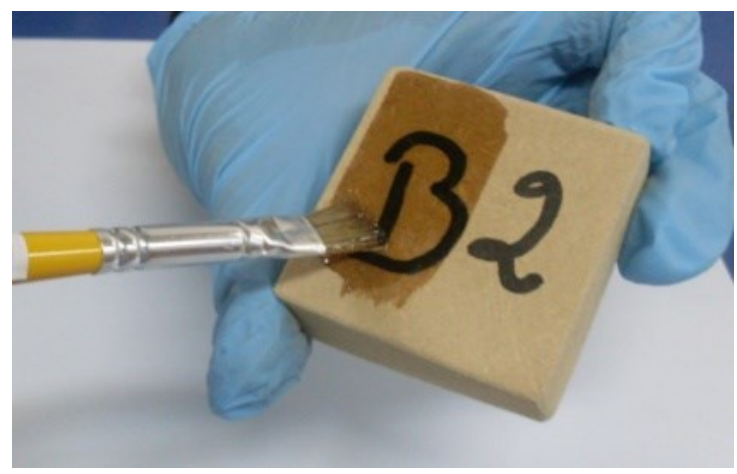

Figure 1: Overlay being applied to the specimen with a brush.

\subsection{Water absorption test}

In Torquato [11] European standards are among the highest in relation to the use of wood-based products with reference to Brazilian producers, and are used for the implementation of the water absorption test. Thus, the EN 317 standard refers to the determination of thickness swelling after immersion in water [12].

As is normal, proof samples must have dimensions of $50 \mathrm{~mm} \times 50 \mathrm{~mm}$. Initially should be weighed in analytical balance and measured the thickness. Then they must be packed in a container with cold water at room temperature. After 2 hours must be removed, excess water removed and held again weighing and thickness measurement. Further, the container should be replaced with more water 22 horas to 24 hours to complete immersion, and their values recorded for determination of water absorption and thickness swelling and volume MDF. So initially, all the samples were weighed on a digital scale of Quimis ${ }^{\circledR}$ brand, to check the dry mass, as shown in Figure 2. 


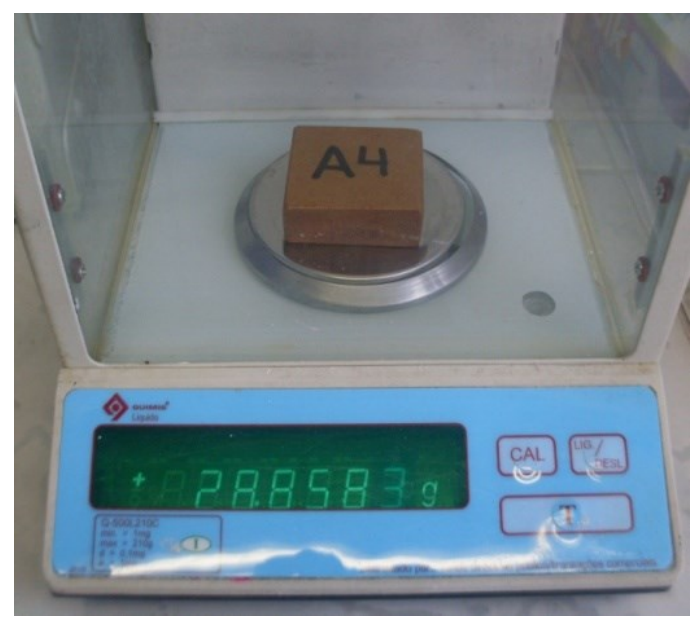

Figure 2: Weighing of the specimens.

The measurement of the specimens to obtain swelling in thickness and volume data was made by means of digital caliper of Starrett巴 brand, as seen in Figure 3.

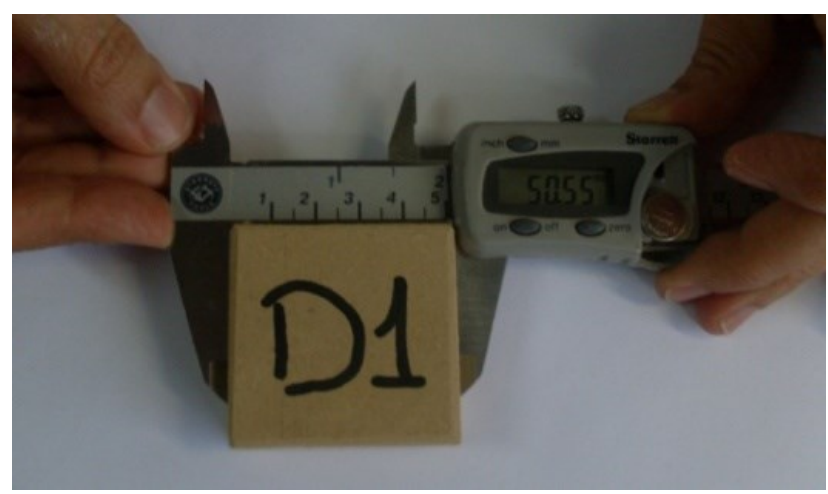

Figure 3: measurement of specimens with a digital caliper.

The values of the weight and dimensions of the specimens were recorded for determination of water absorption, thickness swelling and volume and the percentages calculated from the following formulas:

$$
\mathrm{A} \%=100 \times\left(\mathrm{M}_{2}-\mathrm{M}_{1}\right) / \mathrm{M}_{1}
$$

Where, $\mathrm{A} \%$ is the water absorption in percent, $\mathrm{M}_{1}$ is the initial mass of the test sample in grams and $\mathrm{M}_{2}$ is the mass end of the specimen after testing in grams.

$$
\mathrm{I} \%=100 \times\left(\mathrm{I}_{2}-\mathrm{I}_{1}\right) / \mathrm{I}_{1}
$$

Where, $I \%$ is the swelling in percentage, $\mathrm{I}_{1}$ is the initial swelling of the specimen in $\mathrm{mm}^{3}$ and $\mathrm{I}_{2}$ is the final swelling of the specimen in $\mathrm{mm}^{3}$.

$$
\mathrm{V} \%=100 \times\left(\mathrm{V}_{2}-\mathrm{V}_{1}\right) / \mathrm{V}_{1}
$$

Where $\mathrm{V} \%$ is the Volume in percentage, $\mathrm{V}_{1}$ is the initial volume of the specimen in $\mathrm{mm}^{3}$ and $\mathrm{V}_{2}$ is the final volume of the specimen in $\mathrm{mm}^{3}$.

\subsection{Scanning electron microscopy (SEM)}

In order to check the surface morphology of MDF with different coatings before and after the test water absorption, was held scanning electron microscopy. According Canevarolo [13] this tool allows the study of fine structure and morphology of materials. We used the JSM-6060 equipment, Jeol ${ }^{\circledR}$ brand of LDSM, wherein the magnification of the image reaches the order of 30,000 times and the analytical conditions for obtaining images of backsactteredelectron type (BSE) was $15 \mathrm{KeV}$ to accelerate the electron beam and 
maximum magnification of 4,000 times order.

\section{RESULTS AND DISCUSSION}

For the water absorption test, before immersion in distilled water, the samples were weighed and measured. Further, they were immersed in containers containing $250 \mathrm{ml}$ of distilled water, and after 2 hours and 24 hours were weighed, and carried out the measurement again.

For determining water absorption of the weighing data were tabulated, as can be seen in Table 2, and the results are shown in the Figure 4 graph.

Table 2: Values of water absorption of the specimens subjected to the water absorption test as a function of time.

\begin{tabular}{l|l}
\hline \multicolumn{1}{c|}{ PROOF SAMPLE } & \multicolumn{1}{c}{ COATING } \\
\hline $\mathrm{A} 1-\mathrm{A} 2-\mathrm{A} 3$ & Polyurethane resin on castor oil-based (3 coats) \\
\hline $\mathrm{B} 1-\mathrm{B} 2-\mathrm{B} 3$ & Acrylic varnish (3 coats) \\
\hline $\mathrm{C} 1-\mathrm{C} 2-\mathrm{C} 3$ & Marine varnish (3 coats) \\
\hline $\mathrm{D} 1-\mathrm{D} 2-\mathrm{D} 3$ & Uncoating \\
\hline
\end{tabular}

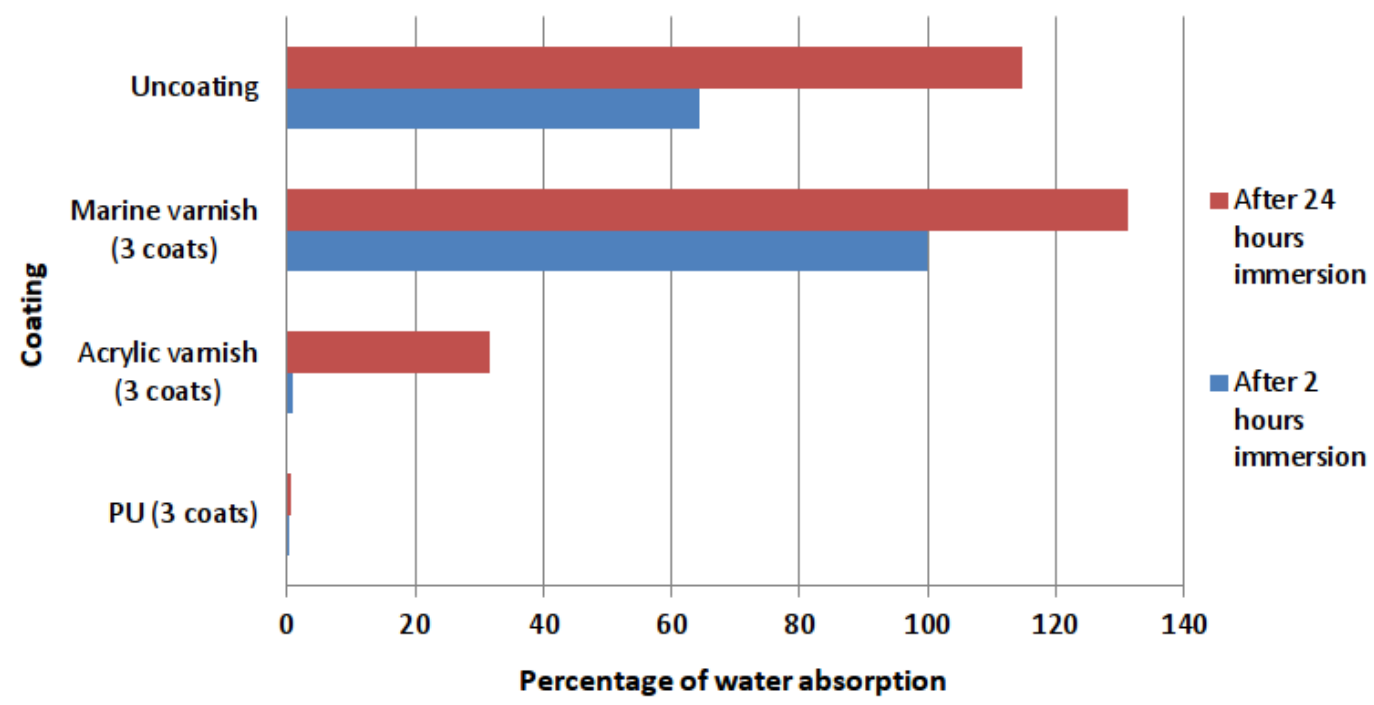

Figure 4: Water absorption results in the various coatings tested.

From the graph display, it can be concluded that the best result waterproofing MDF was presented by plant polyurethane resin on castor oil-based, followed by acrylic varnish. It can be seen that the acrylic lacquer showed discrepancy in water absorption values at 2hours and after 24 hours immersion, with a difference of $30 \%$. Thus, it can be considered that this patent is not suitable for sealing MDF for long periods of water contact. Marine varnish already been recoating what obtained the highest rates of water absorption, both in 2 hours as the 24 hours of immersion of the specimens, even compared to the MDF without coating. This may be associated with the single coating which caused cracks in the MDF during immersion, as can be seen in figure 5, which may have caused the increased absorption of water, since there is a greater exposed area of MDF. As illustrated in this figure, the specimen is immersed for 24 hours with higher cracking. Therefore, it is concluded that this coating is not suitable for sealing of raw MDF. 

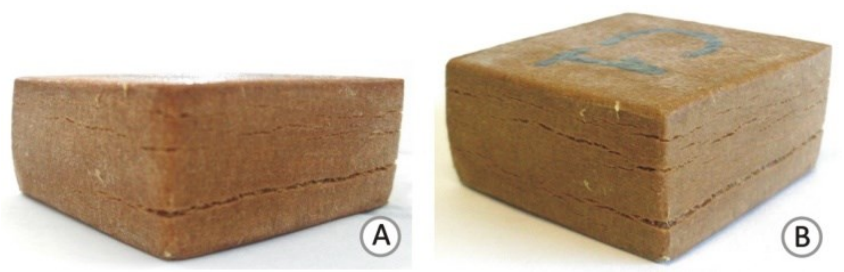

Figure 5: cracks in the coated specimen with marine varnish A) after immersion 2hours and B) after 24 hours of immersion.

In relation to the mass difference MDF, as illustrated in the graph of Figure 6, note that the coating over the plant polyurethane resin, which was less varied throughout the assay process. Since the specimens covered with marine varnish were the ones that had mass increase, especially after 24 hours of immersion.

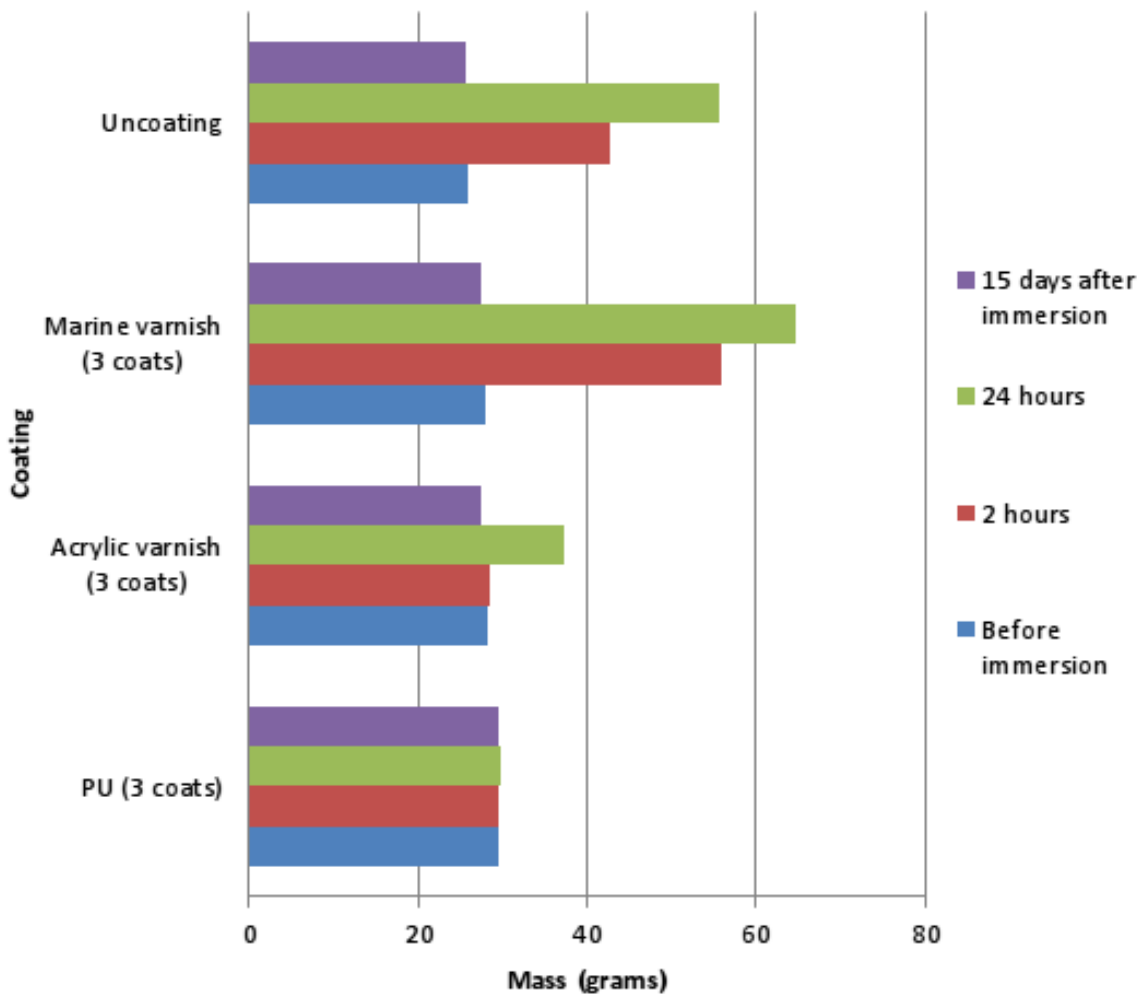

Figure 6: Comparison of the mass of the specimens tested in different coatings.

For swelling finding thickness measurement data of the specimens were tabulated, as can be seen in Table 3, and the results are shown in the Figure 7 graph.

Table 3: Values of thickness swelling of the specimens subjected to the test of water absorption according to time.

\section{THICKNESS SWELLING (\%)}

\begin{tabular}{l|l|l|l}
\hline Specimens & $\begin{array}{l}\text { After } 2 \mathrm{~h} \text { of } \\
\text { Water Immersion }\end{array}$ & $\begin{array}{l}\text { After 24 of } \\
\text { Water Immersion }\end{array}$ & After 15 days of trials \\
\hline A & 1,54 & 2,00 & 1,48 \\
\hline B & 0,80 & 13,52 & 3,62 \\
\hline C & 24,55 & 37,97 & 25,12 \\
\hline D & 36,19 & 40,97 & 24,95 \\
\hline
\end{tabular}




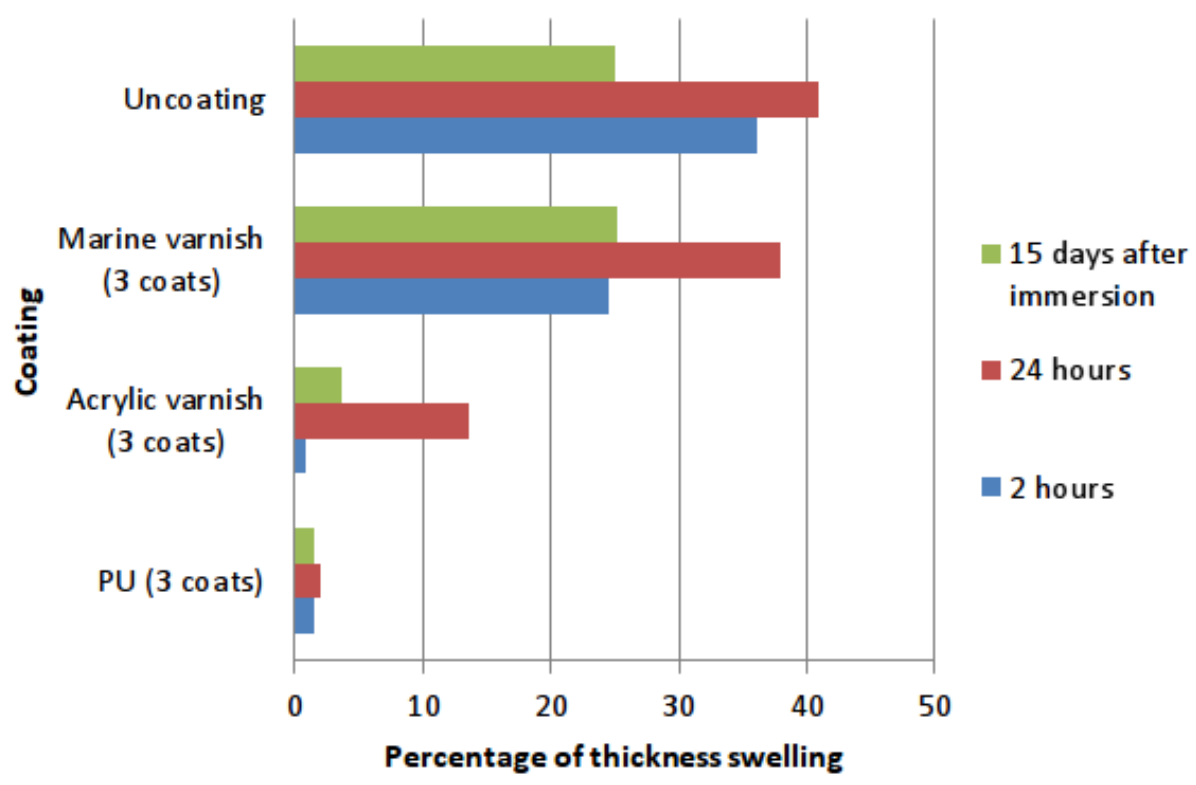

Figure 7: Results of thickness swelling of various coatings tested.

As can be seen in the graph, the lower thickness swelling occurred in the test specimens coated with vegetal polyurethane resin. The samples coated with acrylic varnish had low percentage of thickness swelling in the first 2 hours soaking, but after 24 hours the swelling increased considerably, occurring the same with the percentage of water absorption. Regarding test specimens with marine varnish, it was the most swell in thickness compared to other coatings. However, without coating MDF had the highest percentage of thickness swelling. Note that the percentage of water absorption and swelling are directly proportional, that is, the higher the water absorption and swelling, which is in agreement with the study of Eleoterio [5] which states that the absorption water determines the swelling, which explains the correlation between these two variables.

In Figure 8, specimens in front view are visualized, is possible to observe the comparison of the increase in thickness after immersion for 24 hours, and Figure 9 illustrates the thickness of MDF after 15 days of the trials, in which note- that the specimens desincharam, but did not return the initial thickness, as the chart data point.

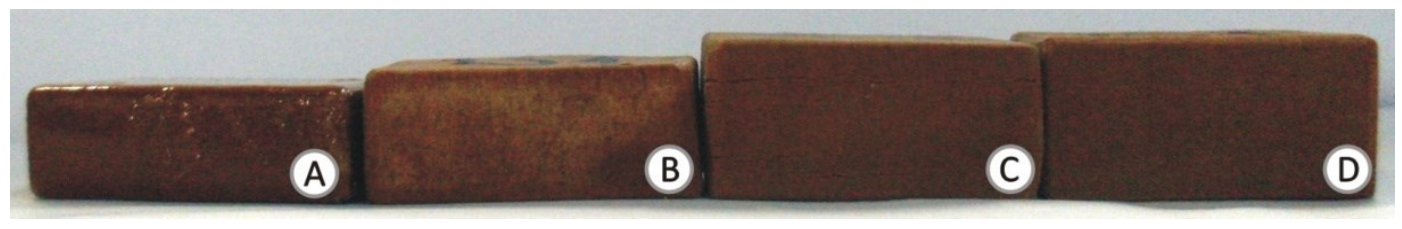

Figure 8: Front view of the specimens after immersion of 24 hours, A) coating depoliuretano based resin from castor oil, B) coated with acrylic varnish, C) coating with marine varnish and D) uncoated.

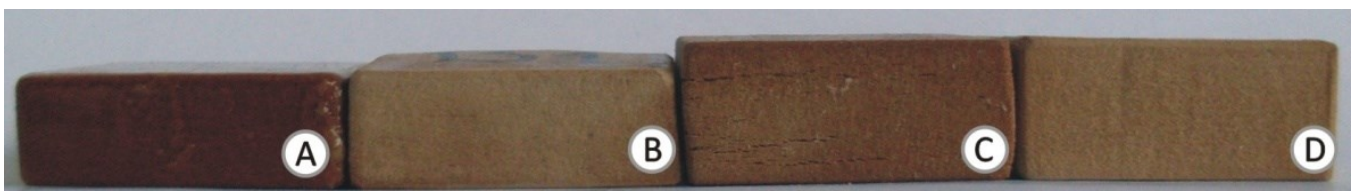

Figure 9: Front view of the specimens after 15 days of trial A) coating with polyurethane resin-based oil of castor (3 coats), B) coated with acrylic varnish, C) coating with marine varnish and D) without coating.

Besides the swelling percentage in thickness was observed swelling percentage in volume of specimens. Thus, Table 4 presents these values, and in Figure 10 you can see the graph. 
Table 4: Values of volume swelling of the test specimens subjected to the test of water absorption according to time.

\begin{tabular}{l|l|l|l}
\hline \multicolumn{4}{|c}{ SWELLING IN VOLUME (\%) } \\
\hline Specimens & $\begin{array}{l}\text { After 2h of Water } \\
\text { Immersion }\end{array}$ & $\begin{array}{l}\text { After 24h of } \\
\text { Water Immersion }\end{array}$ & After 15 days of trial \\
\hline A & 2,68 & 3,82 & 3,06 \\
\hline B & 1,04 & 14,54 & 3,32 \\
\hline C & 17,12 & 31,06 & 17,52 \\
\hline D & 19,53 & 42,19 & 26,62 \\
\hline
\end{tabular}

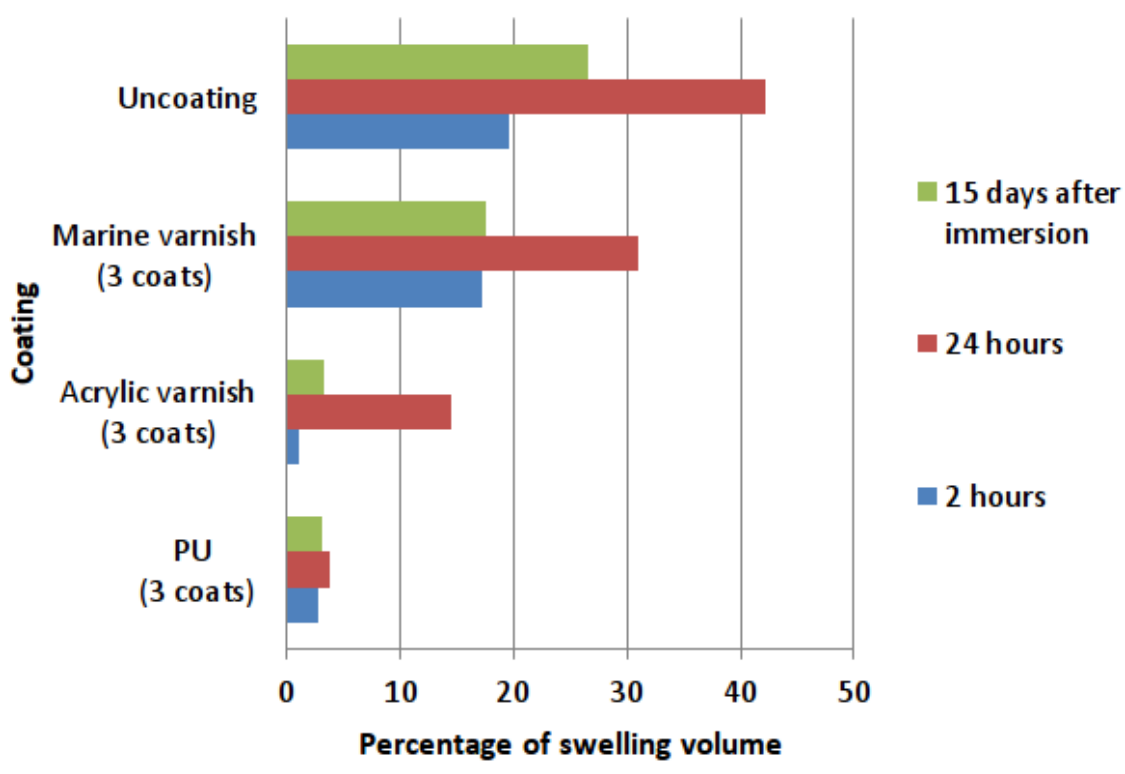

Figure 10: Results of the swelling volume in the various coatings tested.

The swelling results in thickness are in line with those recorded in swelling volume, ie, the best results are vegetal polyurethane resin, acrylic varnish presents itself as an intermediary and marine varnish was covering that had the highest percentage of swelling by volume with respect to the other coatings. In Figure 11 , one can visually check the swelling volume of the samples taken from the water after 24 hours immersion.
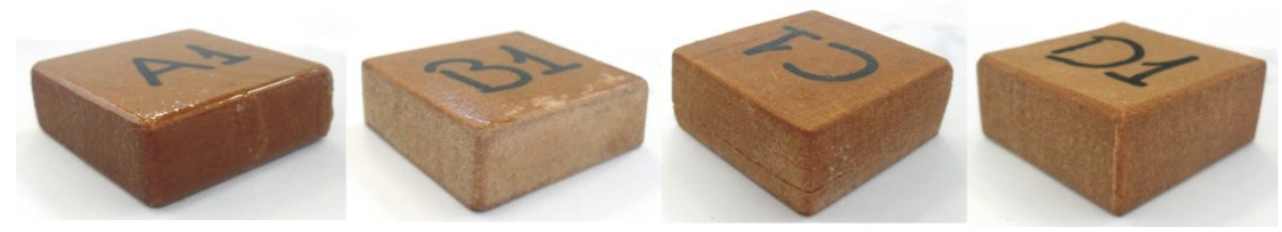

Figure 11: Specimens after 24 hours of immersion.

The visual and tactile aspect of the specimens, 15 days after test, as illustrated in Figure 11, corroborates data from graphs. In MDF coated with vegetable polyurethane resin, apparently, there were no changes on the surface, ie, the material continued with the plasticized aspect and gloss, however, there was a small increase in thickness and volume; those coated with acrylic lacquer had increased thickness and volume, shape deformation by camber and discolouration of the lacquer spots which generated; the specimens coated with marine varnish showed large increase in thickness and volume, cracks and stains; coating occurred in those without large swell in the thickness and volume and surface discoloration.

In order to check the surface of the specimens before and after water absorption test were generated images via Scanning Electron Microscopy, as can be seen in Table 5. 
Table 5: SEM images via the specimens before immersion and dry after 24 hours immersion.

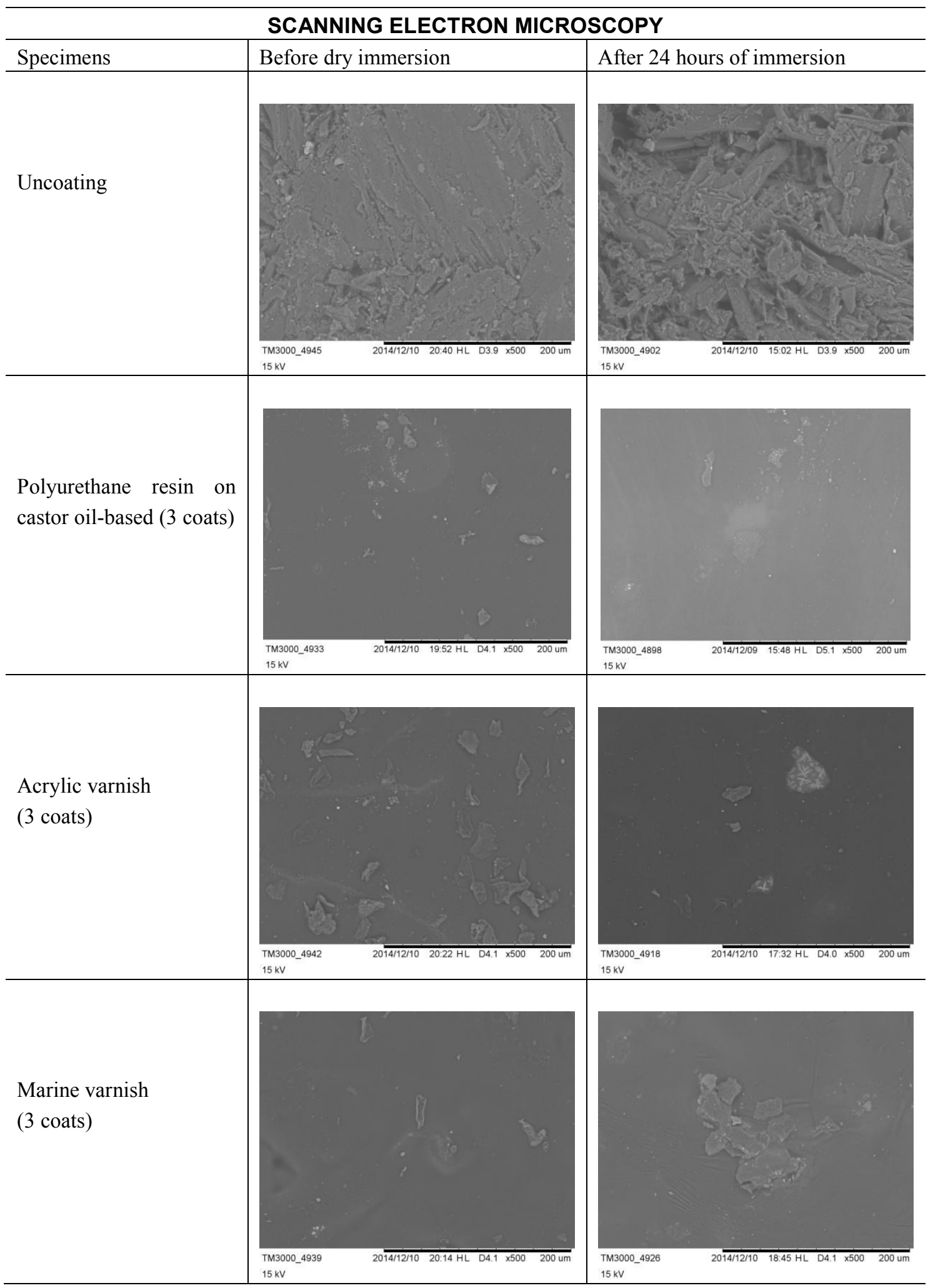

From the observation of the images, we can say that all coating materials completely covered the surface of the MDF, it is not possible to visualize the fibers. Thus, the images show that there are no significant differences in the surface of the MDF before and after immersion, despite the visual appearance of specimens covered with acrylic varnish submit patches that are possibly associated with the loss of varnish. The most significant changes were observed on the surface of the uncoated specimens in the soaking increased porosity of the material, which demonstrates that the raw MDF require waterproofing. 


\section{CONCLUSIONS}

The water absorption test is an important technique for the characterization of materials, because through it you can check water resistance. In the case of MDF study data showed that this material exhibits high water absorption index, had an increase of $114 \%$ in mass after immersion for 24 hours. And after completely dry the samples not fully, which causes deformation of the material. Thus, it is necessary waterproofing of this material from being damaged, and mainly, to broaden the range of applications in product development.

In this context, in water absorption it is concluded that MDF coated with vegetal polyurethane resin castor oil-based, with application in three coats showed lower water absorption. The specimens coated with this material have a mass increase of only $0.74 \%$ after 24 hours immersion. Marine varnish already been recoating with the highest percentage of water absorption, with mass increase in $131 \%$ after 24 hours of immersion. Regarding the thickness swelling volume and the results show that vegetal polyurethane resin was swelled less than what was expected, because the higher the water absorption and swelling. Thus, this work revealed that vegetal polyurethane resin castor oil-based was the best waterproofing tested on MDF.

Therefore, this research has shown that the use of waterproofing for renewable MDF is effective and can replace other non-renewable sources. Thus, this is an attractive alternative from an environmental point of view, especially if the product design using MDF is developed in an ecological perspective.

\section{ACKNOWLEDGEMENTS}

The authors thank CAPES for their financial support and Imperveg S.A. for providing the castor oil based polyurethane.

\section{BIBLIOGRAPHY}

[1] GONZAGA, A.L., Madeira: uso e conservação, Brasília, DF, IPHAN/Monumenta, 2006.

[2] ASSOCIAÇÃO BRASILEIRA DA INDÚSTRIA DE PAINÉIS DE MADEIRA, http://www.abipa.org.br/produtosMDF.php. Acessado em dezembro de 2015.

[3] ASSOCIAÇÃO DAS INDÚSTRIAS DE MÓVEIS DO ESTADO DO RIO GRANDE DO SUL, www.movergs.com.br/views/imagem_pdf.php?pasta=panorama_setor_moveleiro. Acessado em dezembro de 2015.

[4] JUNIOR, E.F.C., SILVA, M.C., CASSILHA, A.C., et al., "Indústria moveleira e resíduos sólidos: considerações para o equilíbrio ambiental”, Revista Educação \& Tecnologia, v.8, pp. 209 - 228, 2003.

[5] ELEOTÉRIO, J. R., Propriedades fisicas de painéis MDF de diferentes densidades e teores de resina, Dissertação de M.Sc., Universidade de São Paulo, Piracicaba, SP, 2000.

[6] VIDOR, F.L.R., Avaliação de processo de inspeção e retratamento de postes de madeira, Dissertação de M.Sc., Pontífica Universidade Católica do Rio Grande do Sul, Porto Alegre, RS, 2006.

[7] APPEL, J. S. L., TERESCOVA, V., RODRIGUES, V. C. B., et al., “Aspectos toxicológicos do preservativo de madeira CCA (arseniato de cobre cromatado): revisão", Revista Brasileira de Toxicologia, v. 19, n. 1, pp. $33-47,2006$.

[8] MORESCHI, J. C., http://engmadeira.yolasite.com/resources/Preservantesdemadeira.pdf. Acessado em junho de 2015.

[9] DIAS, F. M. Aplicação de resina poliuretana à base de mamona na fabricação de painéis de madeira compensada e aglomerad, Tese de D.Sc., Ciências e Engenharia dos Materiais, Universidade de São Paulo, SP, 2005.

[10] IMPERVEG, http://imperveg.com.br/poliuretano-vegetal-imperveg/. Acessado em 20 julho de 2015.

[11] TORQUATO, L.P., Caracterização dos painéis MDF comerciais produzidos no Brasil, Dissertação de M.Sc., Pós-Graduação em Engenharia Florestal, Setor de Ciências Agrárias, Universidade Federal do Paraná, Curitiba, PR, 2008.

[12] EUROPEAN COMMITTEE FOR STANDARDIZATION, European Standard EN 317- Particleboards and Fiberboards - Determination of swelling in thickness after immersion in water, Bruxelas, 1993.

[13] CANEVAROLO, S. V. Técnicas de caracterização de polímeros, São Paulo, Artliber Editora, 2003. 